\title{
An efficient synthesis of 3-ethoxypyrrolidine-2,5-diones and cis-2,3,3a,6a-tetrahydrofuro[2,3-c]pyrrole-4,6(5H)-diones from $\beta$-cyanocarboxylic acids
}

\author{
Nilo Zanatta,* Fabio M. da Silva, Andreia M. P. W. da Silva, Estefania da C. Aquino, \\ Helio G. Bonacorso and Marcos A. P. Martins
}

Núcleo de Química de Heterociclos (NUQUIMHE), Departamento de Química, Universidade Federal de Santa Maria, 97.105-900, Santa Maria, RS, Brazil

E-mail: zanatta@base.ufsm.br

\begin{abstract}
A simple and convenient procedure for the synthesis of a new series of 3-ethoxypyrrolidine-2,5diones and cis-2,3,3a,6a-tetrahydrofuro[2,3-c]pyrrole-4,6(5H)-diones derivatives is described. All compounds were obtained from the direct cyclization of two $\beta$-cyanocarboxylic acids with primary amines and amino alcohols in short reaction time and good yields.
\end{abstract}

Keywords: $\beta$-Cyanocarboxylic acids, succinimides, pyrrolidin-2,5-diones, primary amines

\section{Introduction}

Pyrrolidin-2,5-diones, commonly referred to as succinimides, are cyclic imides structurally characterized by the presence of the fragment - $(\mathrm{CO}) \mathrm{NR}(\mathrm{CO})$ - as belonging to the five-membered ring. ${ }^{1}$ These imides show great bioactive and pharmacological potential acting as enzyme inhibitors, ${ }^{2}$ analgesics, ${ }^{3}$ antimicrobial agents, ${ }^{4}$ anxiolytics, ${ }^{5}$ cytotoxic, ${ }^{6}$ but mainly as anticonvulsants. $^{7}$ The anticonvulsant action of these compounds can be exemplified by ethosuximide (Figure 1), one of the first drugs used to treat epilepsy. Often this pharmacological activity is justified by the presence of the $-\mathrm{CO}(\mathrm{NR}) \mathrm{CO}$ - fragment in their structures, ${ }^{8}$ which is present in molecules of other drugs with anticonvulsant activity recognized as, for example, phenobarbital and phenytoin (Figure 1). 


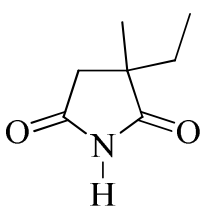

Ethosuximide

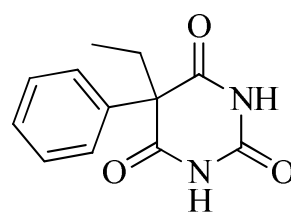

Phenobarbital

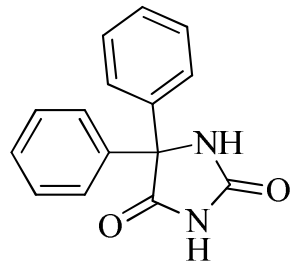

Phenytoin

Figure 1. Anticonvulsant drugs containing the fragment -(CO)NR(CO)-.

Several methods for the synthesis of succinimides are described in the literature. A method commonly used to obtain these compounds involves cyclization reactions of succinic anhydrides, succinic or succinamic acids with nitrogen nucleophiles such as amines, hydrazines and hydrazides. ${ }^{2,9}$ In general, these reactions are carried out in aqueous solution and high temperatures. Usually, succinic acids are obtained by the hydrolysis of the cyano group of dinitriles, ${ }^{10}$ whereas, procedure for the synthesis of succinimides, without carrying out first the hydrolysis of the $\mathrm{CN}$ group, is underexplored. ${ }^{11}$ Recently it has been reported that succinimides can also be synthesized by addition reactions of amines to olefinic bond of maleimides, ${ }^{12}$ by ring expansion of $\beta$-lactams, ${ }^{13}$ by carbonylation reactions of alkynes ${ }^{14}$ and $\alpha, \beta$-unsaturated amides ${ }^{15}$ or biotransformation of maleimides promoted by fungi. ${ }^{16}$ However, these methods, except one which is carried out by the reaction of amines with maleimides, involve catalysts of difficult access and reaction mechanisms still poorly understood.

We postulated that the readily available $\beta$-cyanocarboxylic acids could be convenient building blocks for the synthesis of new series of $N$-substituted 3-ethoxypyrrolidine-2,5-diones and cis-2,3,3a,6a-tetrahydrofuro[2,3-c]pyrrole-4,6(5H)-diones analogous to the ethosuximide drug. We had two paths to carry out the reaction to afford the desired succinimides; by performing first the hydrolysis of the $\beta$-cyano group to a carboxylic acid ${ }^{10}$ followed by the condensation with primary amines, as usually reported, ${ }^{9}$ or to carry out the direct condensation of $\beta$-cyanocarboxylic acids with primary amines, which is the path we are proposing in this study (Scheme 1). The second choice, lead to the desired $N$-substituted succinimides in one-pot reaction and with very good yields. 


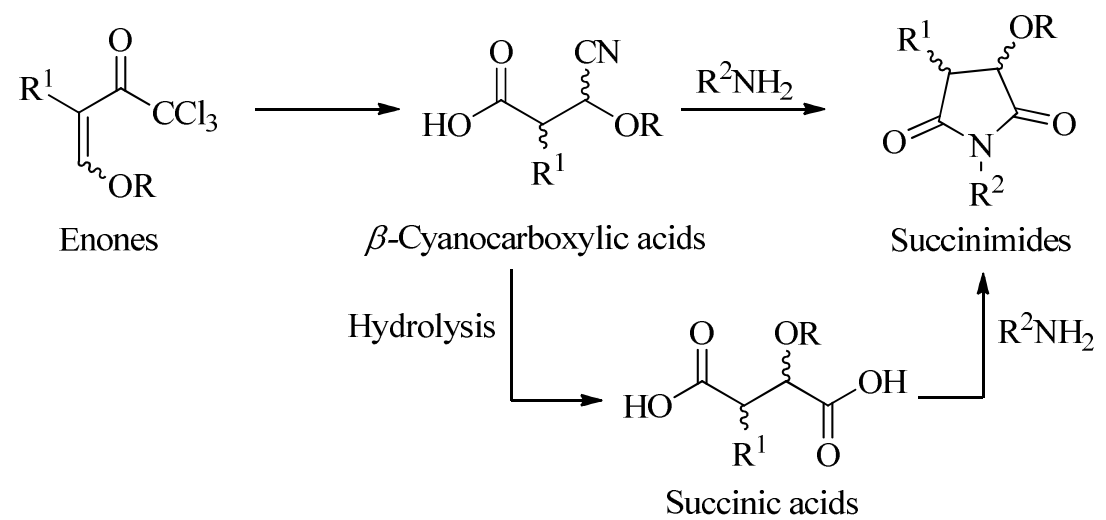

Scheme 1. Synthetic strategy for the synthesis of succinimides.

\section{Results and Discussion}

Scheme 2 outlines the synthesis of the 3-ethoxypyrrolidine-2,5-diones 6a-k and cis-2,3,3a,6atetrahydrofuro[2,3-c]pyrrole-4,6(5H)-diones 7a-k obtained by the direct reaction of 3-cyano-3ethoxypropionic acid $\mathbf{3}$ and 2-cyanotetrahydrofuran-3-carboxylic acid $\mathbf{4}$ with primary amines 5ak. The $\beta$-cyanocarboxylic acids ${ }^{17}$ were previously synthesized by the Michael addition of a cyanide ion to the olefinic bond of two 4-alkoxyvinyl trichloromethyl ketones (trichlorinated enones), a building block prepared from the acylation reactions of vinyl ethers and/or acetals as previously demonstrated $^{18}$ and used for the synthesis of a large scope of heterocyclic compounds. ${ }^{19}$ 


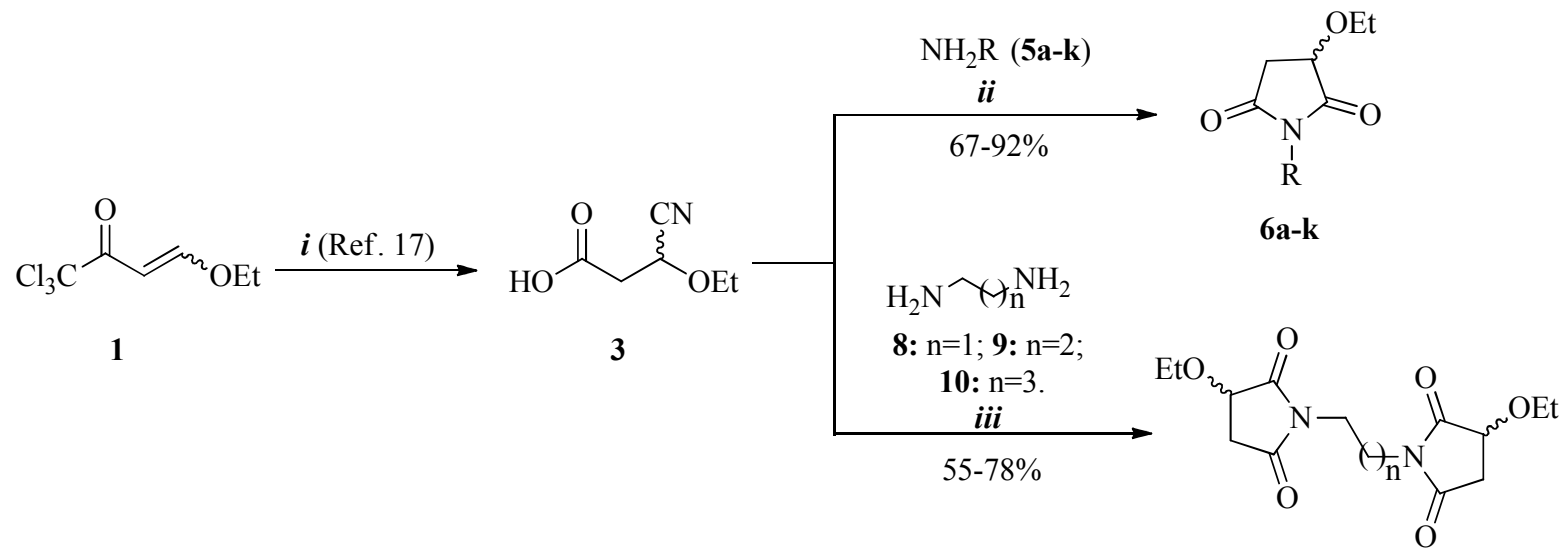

11: $\mathrm{n}=1 ; 12: \mathrm{n}=2 ; 13: \mathrm{n}=3$.

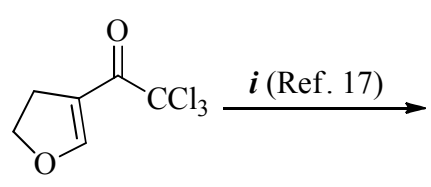

2<smiles>N#CC1OCCC1C(=O)O</smiles>

4

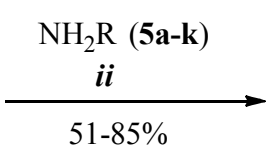<smiles>[R]N1C(=O)C2CCOC2C1=O</smiles>

$7 \mathbf{a}-\mathbf{k}$

$\boldsymbol{i}$ : NaCN/H $\mathrm{H}_{2} \mathrm{O}$, THF, rt, 1-4 h. ii: 1) $\beta$-Cyanocarboxylic acid 3 or 4 (5.0 mmol), amine (5.0 mmol), $\mathrm{H}_{2} \mathrm{O}(10.0 \mathrm{~mL})$ water distillation $\left.\left(140^{\circ} \mathrm{C}\right) ; 2\right)$ Heating $\left(180^{\circ} \mathrm{C}\right), 1.5 \mathrm{~h}$. iii: $\beta$-Cyanocarboxylic acid $3(5.0 \mathrm{mmol})$, amine $(2.5 \mathrm{mmol})$, $\mathrm{H}_{2} \mathrm{O}(10.0 \mathrm{~mL})$, water distillation $\left.\left(140^{\circ} \mathrm{C}\right) ; 2\right)$ Heating $\left(180^{\circ} \mathrm{C}\right), 1.5 \mathrm{~h}$.

\begin{tabular}{cccl}
\hline Compds & \multicolumn{3}{c}{ Compds } \\
$\mathbf{5 , 6 , 7}$ & $\mathrm{R}$ & $\mathbf{5 , 6 , 7}$ & \multicolumn{1}{c}{$\mathrm{R}$} \\
\hline $\mathbf{a}$ & $-\mathrm{CH}_{2}-2-\mathrm{Py}$ & $\mathbf{g}$ & $-\left(\mathrm{CH}_{2}\right)_{2} \mathrm{NEt}_{2}$ \\
$\mathbf{b}$ & $-\mathrm{CH}_{2}-3-\mathrm{Py}$ & $\mathbf{h}$ & $-\left(\mathrm{CH}_{2}\right)_{2} \mathrm{OH}$ \\
$\mathbf{c}$ & $-\mathrm{CH}_{2}-4-\mathrm{Py}$ & $\mathbf{i}$ & $-\left(\mathrm{CH}_{2}\right)_{3} \mathrm{OH}$ \\
$\mathbf{d}$ & $-\mathrm{CH}_{2} \mathrm{C}_{6} \mathrm{H}_{5}$ & $\mathbf{j}$ & $-\mathrm{CH}_{2} \mathrm{CH}(\mathrm{OH}) \mathrm{Me}$ \\
$\mathbf{e}$ & $-\left(\mathrm{CH}_{2}\right)_{2} \mathrm{C}_{6} \mathrm{H}_{5}$ & $\mathbf{k}$ & $-\mathrm{CH}\left(\mathrm{CH}_{2} \mathrm{OH}\right) \mathrm{Et}$ \\
$\mathbf{f}$ & $-\left(\mathrm{CH}_{2}\right)_{2} \mathrm{NMe}_{2}$ & & \\
\hline
\end{tabular}

Scheme 2. The synthesis of 3-ethoxypyrrolidine-2,5-diones 6a-k, cis-2,3,3a,6atetrahydrofuro[2,3-c]pyrrole-4,6(5H)-diones 7a-k and bis-3-ethoxypyrrolidine-2,5-diones 11-13.

The synthesis of 3-ethoxypyrrolidine-2,5-diones $\mathbf{6 a - k}$ and cis-2,3,3a,6a-tetrahydrofuro[2,3c]pyrrole-4,6(5H)-diones 7a-k were carried out using equivalent amounts of $\beta$-cyanocarboxylic acid $\mathbf{3}$ or $\mathbf{4}$ and the corresponding amine 5. Initially, the reagents were dissolved in water and the reactions were heated to about $140{ }^{\circ} \mathrm{C}$ until all the water was distilled off. The reactions were then heated at $180{ }^{\circ} \mathrm{C}$ for $1.5 \mathrm{~h}$, leading to the formation of the succinimides, through pyrolysis of the intermediate amide, in good yields (Table 1). In similar conditions, 3-cyano-3- 
ethoxypropionic acid 3 was reacted with diamines 8-10 to produce bis-3-ethoxypyrrolidine-2,5diones 11-13 in good yields (Table 2).

Table 1. Structures and yields of compounds 6 and 7

\begin{tabular}{|c|c|c|c|c|}
\hline Entry & $\begin{array}{c}\beta \text {-Cyano- } \\
\text { carboxylic acid }\end{array}$ & $\mathrm{R}$ (Amine) & Product & Yield $(\%)^{\mathrm{a}}$ \\
\hline 1 & $\mathbf{3}$ & $-\mathrm{CH}_{2}-2-\mathrm{Py}$ & $6 \mathbf{a}$ & 75 \\
\hline 2 & 3 & $-\mathrm{CH}_{2}-3-\mathrm{Py}$ & $6 \mathbf{b}$ & 78 \\
\hline 3 & 3 & $-\mathrm{CH}_{2}-4-\mathrm{Py}$ & $6 c$ & 90 \\
\hline 4 & 3 & $-\mathrm{CH}_{2} \mathrm{C}_{6} \mathrm{H}_{5}$ & $6 d$ & 83 \\
\hline 5 & 3 & $-\left(\mathrm{CH}_{2}\right)_{2} \mathrm{C}_{6} \mathrm{H}_{5}$ & $6 e$ & 81 \\
\hline 6 & 3 & $-\left(\mathrm{CH}_{2}\right)_{2} \mathrm{NMe}_{2}$ & 6f & 67 \\
\hline 7 & 3 & $-\left(\mathrm{CH}_{2}\right)_{2} \mathrm{NEt}_{2}$ & $6 \mathrm{~g}$ & 71 \\
\hline 8 & 3 & $-\left(\mathrm{CH}_{2}\right)_{2} \mathrm{OH}$ & $6 h$ & 71 \\
\hline 9 & 3 & $-\left(\mathrm{CH}_{2}\right)_{3} \mathrm{OH}$ & $6 \mathbf{i}$ & 92 \\
\hline 10 & 3 & $-\mathrm{CH}_{2} \mathrm{CH}(\mathrm{OH}) \mathrm{Me}$ & $6 \mathbf{j}$ & 76 \\
\hline 11 & 3 & $-\mathrm{CH}\left(\mathrm{CH}_{2} \mathrm{OH}\right) \mathrm{Et}$ & $6 \mathbf{k}$ & 88 \\
\hline 12 & 4 & $-\mathrm{CH}_{2}-2-\mathrm{Py}$ & $7 \mathbf{a}$ & 85 \\
\hline 13 & 4 & $-\mathrm{CH}_{2}-3-\mathrm{Py}$ & $7 b$ & 68 \\
\hline 14 & 4 & $-\mathrm{CH}_{2}-4-\mathrm{Py}$ & $7 \mathrm{c}$ & 51 \\
\hline 15 & 4 & $-\mathrm{CH}_{2} \mathrm{C}_{6} \mathrm{H}_{5}$ & $7 d$ & 73 \\
\hline 16 & 4 & $-\left(\mathrm{CH}_{2}\right)_{2} \mathrm{C}_{6} \mathrm{H}_{5}$ & $7 e$ & 80 \\
\hline 17 & 4 & $-\left(\mathrm{CH}_{2}\right)_{2} \mathrm{NMe}_{2}$ & $7 f$ & 72 \\
\hline 18 & 4 & $-\left(\mathrm{CH}_{2}\right)_{2} \mathrm{NEt}_{2}$ & $7 \mathrm{~g}$ & 77 \\
\hline 19 & 4 & $-\left(\mathrm{CH}_{2}\right)_{2} \mathrm{OH}$ & $7 \mathbf{h}$ & 68 \\
\hline 20 & 4 & $-\left(\mathrm{CH}_{2}\right)_{3} \mathrm{OH}$ & $7 \mathbf{i}$ & 51 \\
\hline 21 & 4 & $-\mathrm{CH}_{2} \mathrm{CH}(\mathrm{OH}) \mathrm{Me}$ & $7 \mathbf{j}$ & 81 \\
\hline 22 & 4 & $-\mathrm{CH}\left(\mathrm{CH}_{2} \mathrm{OH}\right) \mathrm{Et}$ & $7 \mathbf{k}$ & 75 \\
\hline
\end{tabular}

${ }^{a}$ Yields of isolated compounds.

Table 2. Structures and yields of compounds 11-13

\begin{tabular}{ccccc}
\hline Entry & $\begin{array}{c}\beta \text {-Cyano- } \\
\text { carboxylic acid }\end{array}$ & Amine & Product & Yield $(\%)^{\mathrm{a}}$ \\
\hline 1 & $\mathbf{3}$ & $\mathrm{NH}_{2}\left(\mathrm{CH}_{2}\right)_{2} \mathrm{NH}_{2}$ & $\mathbf{1 1}$ & 75 \\
2 & $\mathbf{3}$ & $\mathrm{NH}_{2}\left(\mathrm{CH}_{2}\right)_{3} \mathrm{NH}_{2}$ & $\mathbf{1 2}$ & 55 \\
3 & $\mathbf{3}$ & $\mathrm{NH}_{2}\left(\mathrm{CH}_{2}\right)_{4} \mathrm{NH}_{2}$ & $\mathbf{1 3}$ & 78 \\
\hline
\end{tabular}

${ }^{a}$ Yields of isolated compounds. 
Compounds $\mathbf{6 j}$ and $\mathbf{6 k}$ were obtained as mixtures of diastereoisomers due to the presence of two stereogenic centers in their chemical structures. Although, compound $\mathbf{4}$ has two stereogenic centers, it was obtained as a racemic mixture of isomers, which was evidenced by the presence of only a pair of signal in both ${ }^{1} \mathrm{H}$ and ${ }^{13} \mathrm{C}$ NMR spectroscopy. ${ }^{17}$ In order to verify if intermediate 4 was obtained as the cis- or trans-isomer, a condensation reaction of this compound with primary amines 5a-k was carried out and the corresponding cis-2,3,3a,6a-tetrahydrofuro[2,3-c]pyrrole4,6(5H)-diones 7a-k where obtained (Scheme 3). However, the compounds $\mathbf{7 j}$ and $\mathbf{7 k}$ also showed mixtures of diastereoisomers due to the presence of an additional stereogenic center from the amino alcohols $\mathbf{5} \mathbf{j}$ and $\mathbf{5} \mathbf{k}$.

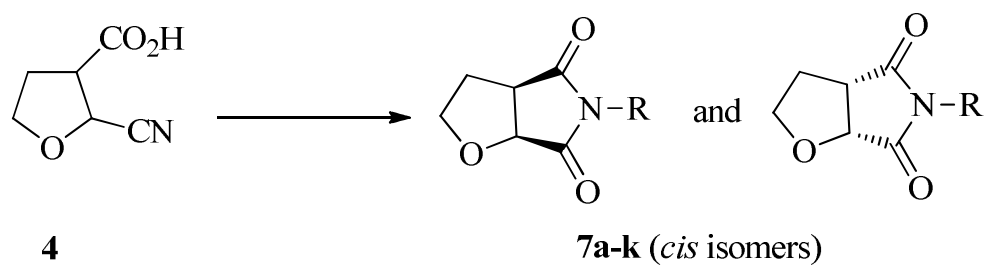

Scheme 3. Cis-isomers of compounds 7a-k.

According to Ibnusaud and Thomas ${ }^{20}$ the reaction of 5-oxotetrahydrofuran-3,4-dicarboxylic esters with primary amines can only lead to the corresponding succinimides if the two carboxyl groups are in cis-position; otherwise, succinamic esters are obtained. Thus, we confirmed that the compound 4 was obtained only as the cis-isomer since the corresponding cis-2,3,3a,6atetrahydrofuro[2,3-c]pyrrole-4,6(5H)-diones 7a-k were the only obtained products.

We propose that the mechanism of formation of 3-ethoxypyrrolidine-2,5-diones and their related compounds, as shown in Scheme 4, starts with the reaction of the carboxylic acid $\mathbf{3}$ with the amines 5a-k leading to the carboxylic acid salt $\mathbf{I}$, which under elevated temperature undergoes pyrolysis giving the amide II. The nitrogen of the amide group of structure II attacks the carbon of the nitrile group forming the cyclic structure III, which under proton transfer, results the pyrrolidinone IV. Compound IV undergoes hydrolysis of the imino group to lead the intermediate $\mathbf{V}$ that is in equilibrium with the structure $\mathbf{V I}$, which by elimination of ammonia, furnishes the 3-ethoxypyrrolidine-2,5-diones 6a-k. This mechanism is also suggested to obtain the corresponding cis-2,3,3a,6a-tetrahydrofuro[2,3-c]pyrrole-4,6(5H)-diones 7a-k. 

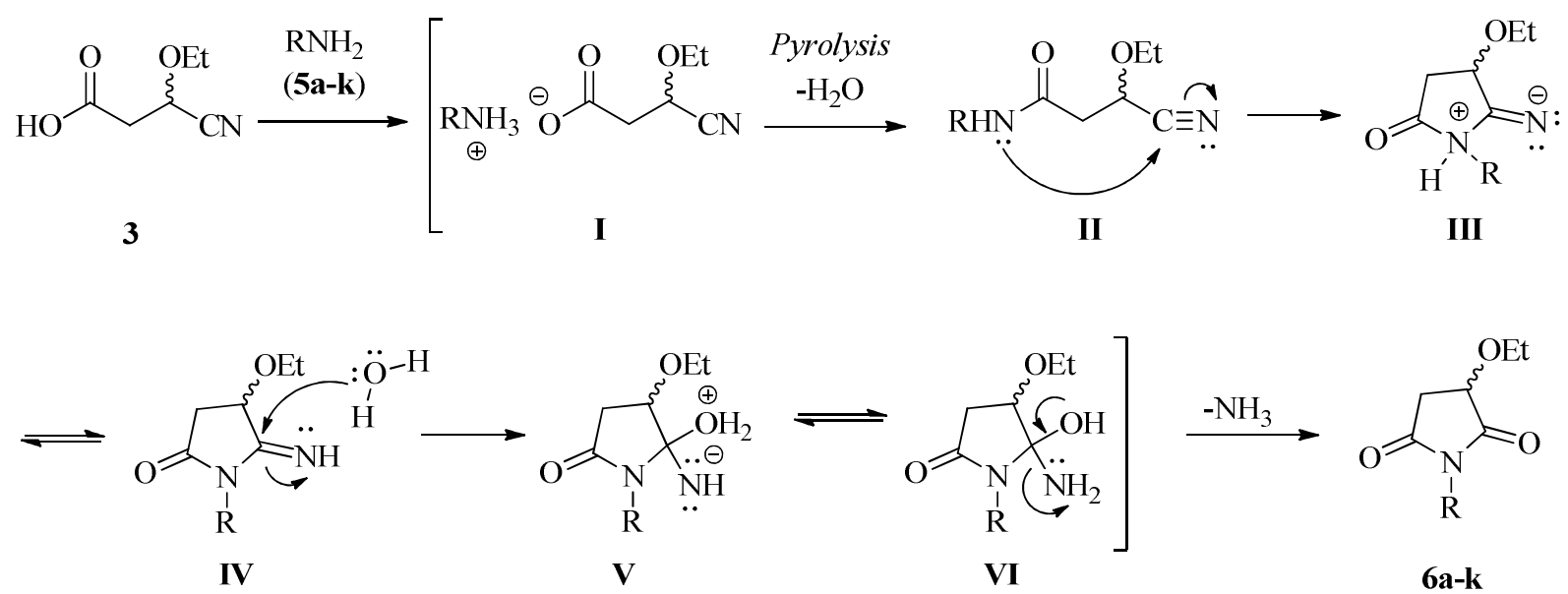

Scheme 4. Mechanism of formation of 3-ethoxypyrrolidine-2,5-diones 6a-k.

\section{Conclusions}

In summary, this study showed a simple and efficient procedure for the synthesis of new series 3-ethoxypyrrolidine-2,5-diones $\mathbf{6 a - k}$, cis-2,3,3a,6a-tetrahydrofuro[2,3-c]pyrrole-4,6(5H)-diones 7a-k, and bis-3-ethoxypyrrolidine-2,5-diones 11-13 that are structurally related to ethosuximide. In addition, this paper presents a new method for the synthesis of succinimides, where the cyclization reaction between the $\beta$-cyanocarboxylic acids and primary amines was carried out directly without the need to previously hydrolyze the nitrile group to carboxylic acid.

\section{Experimental Section}

General. 3-Ethoxypyrrolidine-2,5-diones $\mathbf{6 a - k}$, cis-2,3,3a,6a-tetrahydrofuro[2,3-c]pyrrole4,6(5H)-diones 7a-k, and bis-3-ethoxypyrrolidine-2,5-diones $\mathbf{1 1 - 1 3}$ were identified by ${ }^{1} \mathrm{H}$ and ${ }^{13} \mathrm{C}$ NMR techniques, mass spectrometry (GC-MS), and High Resolution Mass Spectrometry analysis. The correct assignment of the ${ }^{1} \mathrm{H}$ NMR spectra of the products $6 \mathbf{a}-\mathbf{k}, 7 \mathbf{a}-\mathbf{k}$, and 11-13 was carried out using 2D COSY experiment. The High Resolution Mass Spectra (HRMS) were registered on a LC-MS-TOF Bruker Daltonics Micro Ic from the Department of Chemistry of University of São Paulo (USP), São Paulo, SP, Brazil. The mass spectra were registered on an HP 5973 MSD connected to an HP 6890 GC. The GC was equipped with a split-splitless injector, auto-sampler, cross-linked HP-5 capillary column ( $30 \mathrm{~m}, 0.32 \mathrm{~mm}$ of internal diameter), and helium was used as the carrier gas. The ${ }^{1} \mathrm{H}$ and ${ }^{13} \mathrm{C}$ NMR spectra were acquired on a Bruker DPX200 or DPX400 spectrometer in $\mathrm{CDCl}_{3}$ with TMS as the internal reference. 
General experimental procedure for the synthesis of $N$-alkyl(aryl)-3-ethoxypyrrolidine-2,5diones 6a-k and $N$-alkyl(aryl)-cis-2,3,3a,6a-tetrahydrofuro[2,3-c]pyrrole-4,6(5H)-diones 7ak.

To a solution of 3-cyano-3-ethoxypropionic acid $\mathbf{3}$ or 2-cyanotetrahydrofuran-3-carboxylic acid $4(5.0 \mathrm{mmol})$ in water $(10 \mathrm{~mL})$, amines $5 \mathbf{a}-\mathbf{k}(5.0 \mathrm{mmol})$ was added. The reaction mixture was stirred at $140{ }^{\circ} \mathrm{C}$ until all the water was distilled off. After the distillation of the water, the temperature of the oil bath was raised to $180{ }^{\circ} \mathrm{C}$ and the reaction was maintained at this temperature for $1.5 \mathrm{~h}$. The reaction was cooled to room temperature and chloroform $(30 \mathrm{~mL})$ was added to the reaction flask in order to solubilize the remaining oil in the flask. The solution was dried $\left(\mathrm{Na}_{2} \mathrm{SO}_{4}\right)$, filtered and evaporated. Compounds 6 and 7 were obtained as brown or yellow oils in good yields and were purified by column chromatography on silica gel as the stationary phase and $50 \%$ chloroform/ethyl acetate solution as the mobile phase.

\section{Selected spectral data of the products (6 and 7)}

3-Ethoxy-1-(pyridin-2-ylmethyl)pyrrolidine-2,5-dione (6a). Yellow oil; ${ }^{1} \mathrm{H}$ NMR (200 MHz, $\left.\mathrm{CDCl}_{3}\right): \delta 1.26\left(\mathrm{t}, 3 \mathrm{H}, J_{H 7-H 6}\right.$ 7.0, H-7), $2.73\left(\mathrm{dd}, 1 \mathrm{H}, J_{H 4-H 4}, 18.2, J_{H 4-H 3} 4.4, \mathrm{H}-4\right), 3.12$ (dd, $1 \mathrm{H}, J_{H 4^{\prime}-H 4}$ 18.3, $J_{H 4^{\prime}-H 3}$ 8.2, H-4'), 3.63-3.78 (m, 1H, H-6), 3.95-4.10 (m, 1H, H-6'), 4.43 (dd, $\left.1 \mathrm{H}, J_{H 3-H 4}, 8.1, J_{H 3-H 4} 4.4, \mathrm{H}-3\right), 4.83$ (s, 2H, H-8), 7.14-7.26 (m, 2H, H-11, H-13), 7.64 (td, $\left.1 \mathrm{H}, J_{H 12-H 11, H 13} 7.8, J_{H 12-H 10} 1.8, \mathrm{H}-12\right), 8.51\left(\mathrm{~d}, 1 \mathrm{H}, J_{H 10-H 11} 4.8, \mathrm{H}-10\right) .{ }^{13} \mathrm{C}$ NMR $(50 \mathrm{MHz}$, $\left.\mathrm{CDCl}_{3}\right): \delta=15.1(\mathrm{C}-7), 36.3(\mathrm{C}-4), 43.2(\mathrm{C}-8), 66.9(\mathrm{C}-6), 73.4(\mathrm{C}-3), 121.8(\mathrm{C}-11), 122.5$ (C-13), 136.6 (C-12), 149.5 (C-10), 154.1 (C-9), 174.0 (C-2), 175.7 (C-5). GC-MS (EI, 70eV) $m / z$ (\%): $190\left(\mathrm{MH}^{+}\right.$- 45, 100), 162 (4), 135 (38), 93 (47). GC-MS (CI) m/z (\%): $235\left(\mathrm{MH}^{+}, 100\right)$, 263 (10). HRMS (ESI-TOF) Calcd for $\mathrm{C}_{12} \mathrm{H}_{15} \mathrm{~N}_{2} \mathrm{O}_{3}$ : [M+H] ${ }^{+}$235.1082. Found: 235.1087.

3-Ethoxy-1-(phenylmethyl)pyrrolidine-2,5-dione (6d). Yellow oil; ${ }^{1} \mathrm{H}$ NMR (400 MHz, $\mathrm{CDCl}_{3}$ ): $\delta 1.23\left(\mathrm{t}, 3 \mathrm{H}, J_{H 7-H 6} 6.8, \mathrm{H}-7\right), 2.63\left(\mathrm{dd}, 1 \mathrm{H}, J_{H 4-H 4}, 18.4, J_{H 4-H 3} 4.0, \mathrm{H}-4\right), 3.00$ (dd, $1 \mathrm{H}, J_{H 4^{\prime}-H 4}$ 18.0, $J_{H 4^{\prime}-H 3}$ 8.4, H-4'), 3.63-3.71 (m, 1H, H-6), 3.95-4.02 (m, 1H, H-6'), 4.29 (dd, $\left.1 \mathrm{H}, J_{H 3-H 4}, 8.4, J_{H 3-H 4} 4.0, \mathrm{H}-3\right), 4.65$ (s, 2H, H-8), 7.26-7.38 (m, 5H, H-10, H-11, H-12). ${ }^{13} \mathrm{C}$ NMR (100 MHz, $\left.\mathrm{CDCl}_{3}\right): \delta 15.0(\mathrm{C}-7), 36.2(\mathrm{C}-4), 42.2(\mathrm{C}-8), 66.9(\mathrm{C}-6), 73.2(\mathrm{C}-3), 127.9$ (C-12), 128.6 (C-10), 128.7 (C-11), 135.3 (C-9), 173.9 (C-2), 175.6( C-5). GC-MS (EI, 70eV) $m / z(\%): 233\left(\mathrm{M}^{+}, 3\right), 189\left(\mathrm{MH}^{+}-45,100\right), 132$ (100), 91 (100), 55 (54). HRMS (ESI-TOF) Calcd for $\mathrm{C}_{13} \mathrm{H}_{16} \mathrm{NO}_{3}$ : $[\mathrm{M}+\mathrm{H}]^{+}$234.1130. Found: 234.1127.

3-Ethoxy-1-(2-dimethylaminoethyl)pyrrolidine-2,5-dione (6f). Yellow oil; ${ }^{1} \mathrm{H}$ NMR (400 $\mathrm{MHz}_{\mathrm{CDCl}}$ ): $\delta 1.25\left(\mathrm{t}, 3 \mathrm{H}, J_{H 7-H 6} 7.2, \mathrm{H}-7\right), 2.25$ (s, 6H, H-10, H-10'), 2.51 (t, 2H, $J_{H 9-H 8} 6.4$, $\mathrm{H}-9), 2.62\left(\mathrm{dd}, 1 \mathrm{H}, J_{H 4-H 4^{\prime}} 18.0, J_{H 4-H 3} 4.4, \mathrm{H}-4\right), 3.02$ (dd, $1 \mathrm{H}, J_{H 4^{\prime}-H 4} 18.0, J_{H 4^{\prime}-H 3}$ 8.0, H-4'), 3.63 (t, 2H, J $J_{H 8-H 9}$ 6.4, H-8), 3.65-3.72 (m, 1H, H-6), 3.95-4.03 (m, 1H, H-6'), 4.33 (dd, 1H, $\left.J_{H 3-H 4}, 8.4, J_{H 3-H 4} 4.0, \mathrm{H}-3\right) .{ }^{13} \mathrm{C} \mathrm{NMR}\left(100 \mathrm{MHz}, \mathrm{CDCl}_{3}\right): \delta 15.1(\mathrm{C}-7), 36.2(\mathrm{C}-4), 36.4(\mathrm{C}-$ 8), 45.3 (C-10, C-10'), 56.0 (C-9), 66.8 (C-6), 73.2 (C-3), 174.3 (C-2), 176.0 (C-5). GC-MS (EI, 70eV) $\mathrm{m} / \mathrm{z}(\%): 214\left(\mathrm{M}^{+}, 4\right), 71$ (6), 58 (100). HRMS (ESI-TOF) Calcd for $\mathrm{C}_{10} \mathrm{H}_{19} \mathrm{~N}_{2} \mathrm{O}_{3}$ : $[\mathrm{M}+\mathrm{H}]^{+}$215.1395. Found: 215.1393 . 
3-Ethoxy-1-(2-hydroxyethyl)pyrrolidine-2,5-dione (6h). Yellow oil; ${ }^{1} \mathrm{H}$ NMR (200 MHz, $\mathrm{CDCl}_{3}$ ): $\delta 1.26\left(\mathrm{t}, 3 \mathrm{H}, J_{H 7-H 6}\right.$ 7.0, H-7), $2.67\left(\mathrm{dd}, 1 \mathrm{H}, J_{H 4-H 4}, 18.2, J_{H 4-H 3} 4.2, \mathrm{H}-4\right), 3.06$ (dd, $1 \mathrm{H}, J_{H 4^{\prime}-H 4} 18.0, J_{H 4^{\prime}-H 3} 8.2, \mathrm{H}-4$ ') $3.62-3.78$ (m, 5H, H-6, H-8, H-9), 3,90-4,07 (m, 1H, H-6'), $4.36\left(\mathrm{dd}, 1 \mathrm{H}, J_{H 3-H 4}, 8.2, J_{H 3-H 4} 4.2, \mathrm{H}-3\right) .{ }^{13} \mathrm{C} \mathrm{NMR}\left(50 \mathrm{MHz}, \mathrm{CDCl}_{3}\right): \delta 15.1(\mathrm{C}-7), 36.2(\mathrm{C}-$ 4), 41.3 (C-8), 59.9 (C-9), 67.0 (C-6), 73.2 (C-3), 174.9 (C-2), 176.4 (C-5). GC-MS (EI, 70eV) m/z (\%): $143\left(\mathrm{MH}^{+}-45,100\right), 116$ (10), 97 (27), 55 (43). HRMS (ESI-TOF) Calcd for $\mathrm{C}_{8} \mathrm{H}_{14} \mathrm{NO}_{4}:[\mathrm{M}+\mathrm{H}]^{+}$188.0923. Found: 188.0926 .

5-(Pyridin-2-ylmethyl)-2,3,3a,6a-tetrahydrofuro[2,3-c]pyrrole-4,6(5H)-dione (7a). Yellow oil; ${ }^{1} \mathrm{H}$ NMR $\left(200 \mathrm{MHz}, \mathrm{CDCl}_{3}\right.$ ): $\delta$ 2.26-2.37 (m, 2H, H-3, H-3'), 3.47 (ddd, 1H, $J_{H 2-H 2}$ ' 9.2,

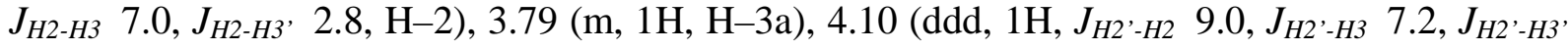
2.8, H-2'), 4.83 (s, 2H, H-7), 4.87 (d, 1H, J J6a-H3a 7.2, H-6a), 7.14-7.22 (m, 2H, H-10, H-12), $7.64\left(\mathrm{td}, 1 \mathrm{H}, J_{H 11-H 10, H 12} 7.6, J_{H 11-H 9} 1.8, \mathrm{H}-11\right), 8.46$ (d, 1H, $\left.J_{H 9-H 10} 4.0, \mathrm{H}-9\right) .{ }^{13} \mathrm{C}$ NMR (50 $\left.\mathrm{MHz}, \mathrm{CDCl}_{3}\right): \delta 30.2(\mathrm{C}-3), 43.3(\mathrm{C}-3 \mathrm{a}), 44.9(\mathrm{C}-7), 68.0(\mathrm{C}-2), 77.7(\mathrm{C}-6 \mathrm{a}), 121.7(\mathrm{C}-10)$, 122.6 (C-12), 136.7 (C-11), 149.4 (C-9), 153.5 (C-8), 174.9 (C-6), 177.0 (C-4). GC-MS (EI, $70 \mathrm{eV}) \mathrm{m} / z$ (\%): $233\left(\mathrm{MH}^{+}, 36\right), 204$ (57), 189 (100), 134 (41), 92 (51), 70 (88). HRMS (ESITOF) Calcd for $\mathrm{C}_{12} \mathrm{H}_{13} \mathrm{~N}_{2} \mathrm{O}_{3}:[\mathrm{M}+\mathrm{H}]^{+}$233.0926. Found: 233.0920 .

5-(1-Phenylmethyl)-2,3,3a,6a-tetrahydrofuro[2,3-c]pyrrole-4,6(5H)-dione (7d). Yellow oil; ${ }^{1} \mathrm{H}$ NMR (200 MHz, CDCl 3 ): $\delta$ 2.17-2.28 (m, 2H, H-3, H-3'), 3.31-3.55 (m, 2H, H-3a, H-2), 3.97-4.07 (m, 1H, H-2'), 4.65 (s, 2H, H-7), 4.74 (d, 1H, J J6a-H3a 7,2, H-6a), 7.27-7.33 (m, 5H, $\mathrm{H}-9, \mathrm{H}-10, \mathrm{H}-11) .{ }^{13} \mathrm{C}$ NMR $\left(50 \mathrm{MHz}, \mathrm{CDCl}_{3}\right): \delta 29.9(\mathrm{C}-3), 42.4(\mathrm{C}-3 \mathrm{a}), 44.7(\mathrm{C}-7), 68.0(\mathrm{C}-$ 2), 77.6 (C-6a), 128.0 (C-11), 128.6 (C-9), 128.6 (C-10), 135.4 (C-8), 174.5 (C-6), 176.7 (C4). GC-MS (EI, 70eV) m/z (\%): $231\left(\mathrm{M}^{+}, 34\right), 203$ (37), 186 (21), 91 (100), 70 (58). HRMS (ESI-TOF) Calcd for $\mathrm{C}_{13} \mathrm{H}_{14} \mathrm{NO}_{3}$ : $[\mathrm{M}+\mathrm{H}]^{+}$232.0973. Found: 232.0965.

5-(2-Dimethylaminoethyl)-2,3,3a,6a-tetrahydrofuro[2,3-c $]$ pyrrole-4,6(5H)-dione

(7f).

Yellow oil; ${ }^{1} \mathrm{H}$ NMR (400 MHz, $\mathrm{CDCl}_{3}$ ): $\delta 2.23$ (s, 6H, H-9, H-9'), 2.26-2.28 (m, 2H, H-3, H3'), 2.51 (t, 2H, $\left.J_{H 8-H 7} 6.4, \mathrm{H}-8\right), 3.36-3.41(\mathrm{~m}, 2 \mathrm{H}, \mathrm{H}-3 \mathrm{a}, \mathrm{H}-2), 3.64$ (t, 2H, $J_{H 7-H 8} 6.4, \mathrm{H}-7$ ), 4.04-4.08 (m, 1H, H-2'), 4.77 (d, 1H, $\left.J_{H 6 a-H 3 a} 7.2, \mathrm{H}-6 \mathrm{a}\right) .{ }^{13} \mathrm{C}$ NMR $\left(100 \mathrm{MHz}, \mathrm{CDCl}_{3}\right): \delta=$ 30.1 (C-3), 36.7 (C-3a), 44.7 (C-7), 45.3 (C-9, C-9’), 55.7 (C-8), 67.7 (C-2), 77.6 (C-6a), 175.0 (C-6), 177.2 (C-4). GC-MS (EI, 70eV) m/z (\%): $212\left(\mathrm{M}^{+}, 2\right), 70$ (4), 58 (100). HRMS (ESI-TOF) Calcd for $\mathrm{C}_{10} \mathrm{H}_{17} \mathrm{~N}_{2} \mathrm{O}_{3}$ : $[\mathrm{M}+\mathrm{H}]^{+}$213.1239. Found: 213.1236.

5-(2-Hydroxyethyl)-2,3,3a,6a-tetrahydrofuro[2,3-c]pyrrole-4,6(5H)-dione (7h). Yellow oil; ${ }^{1} \mathrm{H}$ NMR $\left(200 \mathrm{MHz}, \mathrm{CDCl}_{3}\right): \delta$ 2.22-2.33 (m, 2H, H-3, H-3'), 2.83 (s, 1H, OH), 3.40-3.49 (m,1H, H-3a), 3.55-3.81 (m, 5H, H-7, H-8, H-2), 4.03-4.12 (m, 1H, H-2'), 4.81 (d, 1H, J J 7.2, H-6a). ${ }^{13} \mathrm{C}$ NMR (50 MHz, $\left.\mathrm{CDCl}_{3}\right): \delta 30.0(\mathrm{C}-3), 41.4(\mathrm{C}-3 \mathrm{a}), 44.8(\mathrm{C}-7), 59.5(\mathrm{C}-8), 68.0$ (C-2), 77.7 (C-6a), 175.7 (C-6), 177.8 (C-4). GC-MS (EI, 70eV) m/z (\%): $186\left(\mathrm{MH}^{+}, 10\right), 142$ (100), 70 (57), 56 (29). HRMS (ESI-TOF) Calcd for $\mathrm{C}_{8} \mathrm{H}_{12} \mathrm{NO}_{4}:[\mathrm{M}+\mathrm{H}]^{+}$186.0766. Found: 186.0759 . 
General synthetic procedure for the synthesis of bis-3-ethoxypyrrolidine-2,5-diones 11-13.

Compounds 11-13 were obtained according to the procedure described in this paper to obtain the succinimides $\mathbf{6}$ and 7, but in these cases, compound $\mathbf{3}(5.0 \mathrm{mmol})$ was dissolved in water $(10 \mathrm{~mL})$ and reacted with the diamines 1,2-diaminoethane (8), 1,3-diaminopropane (9) or 1,4diaminobutane (10) (2.5 mmol). The bis-3-ethoxypyrrolidine-2,5-diones 11-13 were obtained as brown oils in moderate yields. Compounds 11-13 were considered pure and were not submitted to further purification.

\section{Selected spectral data of the products (11-13)}

1,1'-(Ethane-1,2-diyl)bis(3-ethoxypyrrolidine-2,5-dione) (11). Brown oil; ${ }^{1} \mathrm{H}$ NMR (200 MHz, $\mathrm{CDCl}_{3}$ ): $\delta 1.24\left(\mathrm{t}, 6 \mathrm{H}, J_{H 7-H 6}\right.$ 7.0, H-7), 2.59 (dd, 2H, $\left.J_{H 4-H 4}, 18.0, J_{H 4-H 3} 4.4, \mathrm{H}-4\right), 2.93$ (dd, $1 \mathrm{H}, J_{H^{\prime}-H 4} 8.2, J_{H 4^{\prime}-H 3} 3.8, \mathrm{H}-4^{\prime}$ ), $3.02\left(\mathrm{dd}, 1 \mathrm{H}, J_{H 4^{\prime}-H 4} 8.0, J_{H 4^{\prime}-H 3} 3.8, \mathrm{H}-4^{\prime}\right.$ ), 3.59-3.77 (m, 6H, $\mathrm{H}-6, \mathrm{H}-8), 3.82-4.01\left(\mathrm{~m}, 2 \mathrm{H}, \mathrm{H}-6\right.$ '), 4.24-4.32 (m, 2H, H-3). ${ }^{13} \mathrm{C}$ NMR $\left(50 \mathrm{MHz}, \mathrm{CDCl}_{3}\right): \delta$ 15.1 (C-7), 36.0 (C-4), 36.7 (C-8), 66.8 (C-6), 73.2 (C-3), $174.4(\mathrm{C}-2), 174.5(\mathrm{C}-2), 176.1$ (C5), 176.2 (C-5). GC-MS (EI, 70eV) m/z (\%): $312\left(\mathrm{M}^{+}, 1\right), 268\left(\mathrm{MH}^{+}-45,51\right), 224$ (100), 187 (30), 125 (39), 72 (34), 55 (38). HRMS (ESI-TOF) Calcd for $\mathrm{C}_{14} \mathrm{H}_{20} \mathrm{~N}_{2} \mathrm{O}_{6} \mathrm{Na}$ : $[\mathrm{M}+\mathrm{H}]^{+} 335.1219$. Found: 335.1216.

\section{Supplementary Material Available}

Experimental procedures, characterization data (for all the products), copies of ${ }^{1} \mathrm{H}$ and ${ }^{13} \mathrm{C} \mathrm{NMR}$ spectra associated with this paper can be found in the online version.

\section{Acknowledgements}

The authors thank the financial support from the Fundação de Apoio à Tecnologia e Ciência do Estado do Rio Grande do Sul (FAPERGS, PRONEX No. 10/0037-8), and Conselho Nacional de Desenvolvimento Científico e Tecnológico (CNPq - Universal grant No. 473512/2009-2) and fellowships from CNPq (F. M. S., E. C. A.), CAPES (F. M. S.), and FAPERGS (A. M. P. W. S.).

\section{References}

1. (a) Hargreaves, M. K.; Pritchard, J. G.; Dave, H. R. Chem. Rev. 1970, 70, 439. (b) Flaih, N.; Pham-Huy, C.; Galons, H. Tetrahedron Lett. 1999, 40, 3697.

2. Groutas, W. C.; Brubaker, M. J.; Stanga, M. A.; Castrisos, J. C.; Crowley, J. P.; Schatz, E. J. J. Med. Chem. 1989, 32, 1607. 
3. (a) Filho, V. C.; Corrêa, R.; Vaz, Z.; Calixto, J. B.; Nunes, R. J.; Pinheiro, T. R.; Andricopulo, A. D.; Yunes, R. A. Il Farmaco 1998, 53, 55. (b) Shannon, H. E.; Eberle, E. L.; Peters, S. C. Neuropharmacology 2005, 48, 1012.

4. (a) Filho, V. C.; Queiroz, E. F.; Lima, E. O.; Pinheiro, T. R.; Nunes, R. J.; Yunes, R. A. Quím. Nova 1996, 19, 590. (b) Andricopulo, A. D.; Yunes, R. A.; Nunes, R.J.; Savi, A. O. S.; Corrêa, R.; Cruz, A. B.; Filho, V. C. Quím Nova 1998, 21, 573. (c) Zentz, F.; Valla, A.; Guillou, R.; Labia, R.; Mathot, A.; Sirot, D. Il Farmaco 2002, 57, 421.

5. Kossakowski, J.; Jarocka, M. Il Farmaco 2001, 56, 785.

6. Zents, F.; Guillou, R. L.; Labia, R.; Sirot, D.; Linard, B.; Valla, A. Il Farmaco 2004, 59, 879.

7. (a) Goehring, R. R.; Greenwood, T. D.; Pisipati, J. S.; Wolfe, J. F. J. Pharm. Sci. 1991, 80, 790. (b) Luszczki, J. J.; Kocharov, S. L.; Cruczwar, S. J. Neurosci. Res. 2009, 64, 267.

8. Lange, J.; Kázmierski, W.; Daroszewski, J. Pol. J. Pharmacol. Pharm. 1991, 43, 71.

9. (a) Hudkins, R. L.; DeHaven-Hudkins, D. L.; Doukas, P. Bioorg. Med. Chem. Lett. 1997, 7, 979. (b) Tomlinson, A.; Danks, T. N.; Heyes, D. M. Langmuir 1997, 13, 5881. (c) Obsnika, J.; Zejec, A.; Karolak-Wojciechowska, J. Il Farmaco 1999, 54, 423. (d) Mederski, W. W. K. R.; Baumgarth, M.; Germann, M.; Kux, D.; Weizel, T. Tetrahedron Lett. 2003, 44, 2133. (e) Brace, N. O.; Mull, S. G.; J. Fluorine Chem. 2006, 127, 108; Kaminski, K.; Obniska, J. Bioorg. Med. Chem. 2008, 16, 4921. (f) Kaminski, K.; Obniska, J.; Dybala, M. Eur. J. Med. Chem. 2008, 43, 53. (g) Barker, M. D.; Dixon, R. A.; Jones, S.; Marsh, B. J. Chem. Commun. 2008, 2218. (h) Obniska, J.; Kaminski, K.; Skrzynska, D.; Pichor, J. Eur. J. Med. Chem. 2009, 44, 2224.

10. Miller, C. A.; Long, L. M. J. Am. Chem. Soc. 1951, 73, 4895.

11. Hendry, C. M. J. Am. Chem. Soc. 1958, 80, 973.

12. (a) Kolyamshin, O. A.; Danilov V. A. Russ. J. Org. Chem. 2004, 40, 982. (b) Jeschke, P.; Harder, A.; Etzel, W.; Gau, W.; Göhrt, A.; Benet-Buchholz, J.; Thielking, G. Bioorg. Med. Chem. Lett. 2005, 15, 2375.

13. (a) Alcaide, B.; Almendros, P.; Cabrero, G.; Ruiz, M. P. Chem. Commun. 2007, 4788. (b) Li, G.; Li, Y.; Daí, L.; You, S. Org. Lett. 2007, 9, 3519. (c) Domingo, L. R.; Aurell, M. J.; Arnó, M. Tetrahedron 2009, 65, 3432.

14. (a) Driller, K. M.; Klein, H.; Jackstell, R.; Beller, M. Angew. Chem. Int. Ed. 2009, 48, 6041. (b) Prateeptongkum, S.; Driller, K. M.; Jackstell, R.; Spannenberg, A.; Beller, M. Chem. Eur. J. 2010, 16, 9606.

15. Suleiman, R.; Ali, B. E. Tetrahedron Lett. 2010, 51, 3211.

16. (a) Sortino, M. A; Cechinel Filho, V.; Zacchino, S. A. Tetrahedron: Asymmetr. 2009, 20, 1106. (b) Sortino, M.; Zacchino, S. A. Tetrahedron: Asymmetr. 2010, 21, 535.

17. Zanatta, N.; da Silva, F. M; da Rosa, L. S.; Jank, L.; Bonacorso, H. G., Martins, M. A. P. Tetrahedron Lett. 2007, 48, 6531.

18. (a) Effenberger, F.; Maier, R.; Schönwälder, K. H.; Ziegler, T. Chem. Ber. 1982, 115, 2766. (b) Martins, M. A. P.; Cunico, W.; Pereira, C. M. P.; Sinhorin, A. P.; Flores, A. F. C.; Bonacorso, H. G.; Zanatta, N. Curr. Org. Synth. 2004, 1, 391. 
19. (a) Martins, M. A. P.; Pereira, C. M. P.; Beck, P.; Machado, P.; Moura, S.; Teixeira, M. V. M.; Bonacorso, H. G.; Zanatta, N. Tetrahedron Lett. 2003, 44, 6669. (b) Zanatta, N.; Faoro, D.; Silva, S. C.; Bonacorso, H. G.; Martins, M. A. P. Tetrahedron Lett. 2004, 45, 5689. (c) Zanatta, N.; Flores, D. C.; Amaral, S. S.; Bonacorso, H. G.; Martins, M. A. P.; Flores, A. F. C. Synlett 2005, 3079. (d) Zanatta, N.; Alves, S. H.; Coelho, H. S.; Borchhardt, D. M.; Machado, P.; Flores, K.; Silva, F. M.; Spader, T. B.; Santurio, J. M.; Bonacorso, H. G.; Martins, M. A. P. Bioorg. Med. Chem. 2007, 15, 1947. (e) Zanatta, N.; Fantinel, L.; Lourega, R. V.; Bonacorso, H. G.; Martins, M. A. P. Synthesis 2008, 358. (f) Zanatta, N.; Madruga, C. C.; Marisco, P. C.; da Rosa, L. S.; da Silva, F. M.; Bonacorso, H. G.; Martins, M. A. P. J. Heterocycl. Chem. 2010, 47, 1234.

20. Ibnusaud, I,. Thomas, G. Tetrahedron Lett. 2003, 44, 1247.

\section{Graphical Abstract}

An efficient synthesis of
3-ethoxypyrrolidine-2,5-
diones and cis-2,3,3a,6a-
tetrahydrofuro[2,3-
c]pyrrole-4,6(5H)-diones
from $\boldsymbol{\beta}$-cyanocarboxylic
acids
Nilo Zanatta, * Fabio $M$.

